Article

\title{
Molecular Detection of Tick-Borne Agents in Cats from Southeastern and Northern Brazil
}

\author{
Marcos Rogério André ${ }^{1, * \mathbb{D}}$, Ana Cláudia Calchi ${ }^{1}$, Maria Eduarda Chiaradia Furquim ${ }^{1}$, Isabela de Andrade ${ }^{1}$, \\ Paulo Vitor Cadina Arantes ${ }^{1}$, Lara Cristina de Melo Lopes ${ }^{1}$, Iuri Kauan Lins do Nascimento Demarchi ${ }^{2}$, \\ Mayra Araguaia Pereira Figueiredo ${ }^{2}$, Cirilo Antonio de Paula Lima ${ }^{3}$ and Rosangela Zacarias Machado ${ }^{1}$ (D)
}

1 Laboratório de Imunoparasitologia, Departamento de Patologia, Reprodução e Saúde Única一Faculdade de Ciências Agrárias e Veterinárias, Universidade Estadual Paulista, UNESP, Jaboticabal 14884-900, SP, Brazil; ana.calchi@unesp.br (A.C.C.); mecfurquim@yahoo.com.br (M.E.C.F.); isaandrade5743@gmail.com (I.d.A.); paulocadina@gmail.com (P.V.C.A.); laracristinalopes@hotmail.com (L.C.d.M.L.); rzacariasmachado@gmail.com (R.Z.M.)

2 Laboratório de Parasitologia, Entomologia e Biologia Molecular Aplicada à Saúde Única, Universidade Federal de Rondônia, Rolim de Moura 76940-000, RO, Brazil; iuri.demarchi98@gmail.com (I.K.L.d.N.D.); mayra.araguaia@unir.br (M.A.P.F.)

3 Departamento de Cirurgia Veterinária, Universidade Federal de Uberlândia, Uberlândia 38400-902, MG, Brazil; paulalima@ufu.br

* Correspondence: mr.andre@unesp.br; Tel.: +55-(16)-3209-7302; Fax: +55-(16)-3202-4275

Citation: André, M.R.; Calchi, A.C.; Furquim, M.E.C.; de Andrade, I.; Arantes, P.V.C.; de Melo Lopes, L.C.; Demarchi, I.K.L.d.N.; Figueiredo, M.A.P.; de Paula Lima, C.A.; Machado, R.Z. Molecular Detection of Tick-Borne Agents in Cats from Southeastern and Northern Brazil. Pathogens 2022, 11, 106. https:// doi.org/10.3390/pathogens11010106

Academic Editor: Valentina Virginia Ebani

Received: 31 December 2021

Accepted: 14 January 2022

Published: 16 January 2022

Publisher's Note: MDPI stays neutral with regard to jurisdictional claims in published maps and institutional affiliations.

Copyright: (C) 2022 by the authors. Licensee MDPI, Basel, Switzerland. This article is an open access article distributed under the terms and conditions of the Creative Commons Attribution (CC BY) license (https:// creativecommons.org/licenses/by/ $4.0 /)$.

\begin{abstract}
Even though the epidemiology of tick-borne agents (TBA) in dogs has been extensively investigated around the world, the occurrence, vectors involved, and molecular identity of these agents in cats remains elusive in many regions. Among TBA, Ehrlichia, Anaplasma, Babesia, Cytauxzoon, and Hepatozoon are responsible for diseases with non-specific clinical signs in cats, making essential the use of molecular techniques for accurate diagnosis and proper treatment. The present work aimed to investigate the occurrence and molecular identity of tick-borne agents (Ehrlichia, Anaplasma, Babesia/Theileria, Cytauxzoon, and Hepatozoon) in cats from southeastern (states of São Paulo (SP) and Minas Gerais (MG)) and northern (state of Rondônia (RO)) Brazil. For this purpose, 390 blood samples were collected from domiciled cats in MG $(n=155), \mathrm{SP}(n=151)$, and $\mathrm{RO}(n=84)$ states, submitted to DNA extraction and PCR assays for Ehrlichia spp. (dsb gene), Anaplasma spp. (rrs gene), piroplasmids (18S rRNA gene), and Hepatozoon spp. (18S rRNA gene), sequencing, and phylogenetic inferences. The overall positivity for Anaplasma spp., Ehrlichia spp., Babesia/Theileria spp., Cytauxzoon spp., and Hepatozoon spp. were $7.4 \%$ (12.3\% (MG) and 6.6\% (SP)), $2 \%(4.5 \%(\mathrm{MG})$ and $0.6 \%(\mathrm{SP})), 0.7 \%(0.6 \%(\mathrm{MG})$, $0.6 \%$ (SP) and $1.2 \%(\mathrm{RO})), 27.2 \%$ (41.9\% (MG), $24.5 \%(\mathrm{SP})$ and $4.8 \%(\mathrm{RO})$, and $0 \%$, respectively. The phylogenetic analysis grouped the obtained sequences with 'Candidatus Anaplasma amazonensis', $A$. platys, B. vogeli, and Cytauxzoon sp. previously detected in wild felids from Brazil. qPCR specific for E. canis based on the $d s b$ gene confirmed the molecular identity of the detected ehrlichial agent. The present study expanded the list and geographical distribution of hemoparasites in cats. 'Candidatus Anaplasma amazonensis', recently detected in sloths from northern Brazil, was described for the first time in cats. This is the first report of piroplasmids infecting cats in northern Brazil. Coinfection by Cytauxzoon and other TBA (Ehrlichia, Anaplasma, and B. vogeli) reported in the present study raises the need for veterinary practitioners' awareness of cats parasitized by multiple TBA.
\end{abstract}

Keywords: feline; Anaplasma; Ehrlichia; Babesia; Cytauxzoon; Hepatozoon

\section{Introduction}

Even though the epidemiology of tick-borne agents (TBA) in dogs has been extensively investigated around the world, the occurrence, vectors involved, and molecular identity of these agents in cats remains elusive in many regions. Among TBA, Ehrlichia, Anaplasma, Babesia, Cytauxzoon, and Hepatozoon are responsible for diseases with non-specific clinical 
signs in cats, making essential the use of molecular techniques for accurate diagnosis and proper treatment.

Ehrlichia spp. and Anaplasma spp. (Rickettsiales: Anaplasmataceae) comprise Gramnegative obligate intracellular $\alpha$-Proteobacteria that infect erythrocytes, leucocytes, and platelets of several vertebrate species and are mainly transmitted by tick bites [1]. Feline ehrlichiosis and anaplasmosis are characterized by unspecific clinical signs and laboratorial abnormalities, such as anorexia, lethargy, fever, dehydration, anemia, thrombocytopenia, leucocytosis/leucopenia, and pancytopenia [2,3]. The geographical occurrence of Anaplasma and Ehrlichia is associated with that found for their competent vectors: while $R$. sanguineus sensu lato and sensu stricto are the main vectors for E. canis [4] and A. platys [5], respectively, Ixodes pacificus/I. scapularis and Ixodes ricinus are responsible for $A$. phagocytophilum transmission in the USA and Europe, respectively [3].

Feline piroplasmids (Piroplasmida: Babesiidae/Theileriidae) comprise Babesia spp. [6], Theileria spp. [7,8], and Cytauxzoon spp. [9]. While clinical babesiosis associated with infection by Babesia felis, B. leo, B. lengau, and "Babesia species cat Western Cape" has been reported mainly in cats from South Africa, clinical cytauxzoonoosis due Cytauxzoon felis has been reported mostly in cats from the USA [9]. Feline babesiosis is mainly characterized by lethargy, anorexia, and anemia, whereas B. lengau caused cerebral babesiosis [6]. Macrophages infected by Cytauxzoon felis-schizonts can disseminate in several tissues, causing thrombosis, circulatory impairment, systemic inflammatory response, and eventually death. On the other hand, piroplasms parasitizing red blood cells lead to hemolytic anemia and erythrophagocytosis [10]. In the USA, cytauxzoonosis is characterized by a (per)acute severe febrile disease, with non-specific clinical and hematological signs (anorexia, fever, dyspnea, tachycardia, generalized pain, vocalization, anemia, thrombocytopenia, leucopenia, hepato/splenomegaly, neurological signs, etc.) [10]. Even though piroplasmids phylogenetically related to Theileria equi and ruminant-associated Theileria have been detected in cats from Brazil [7,8], clinical signs associated with infection by these theileriids have not been reported. Amblyomma americanum and Dermacentor variabilis are the main vectors of Cytauxzoon felis in the USA [10], whereas the vectors for feline-associated Babesia are still unknown.

Apicomplexan protozoans of the genus Hepatozoon sp. (Adeleorina: Hepatozoidae) share a general life cycle, which includes sexual reproduction and sporogony in a hematophagous invertebrate definitive host and merogony followed by gametogony in an intermediate vertebrate host. Hepatozoon transmission occurs by ingestion of the definitive host, represented by an invertebrate containing Hepatozoon oocysts, by the intermediate host [11]. Although the transmission route has not yet been elucidated for feline hepatozoonosis, the association of Hepatozoon infection in cats with outdoor access suggests the potential transmission by arthropod vectors or by predation [12]. Indeed, Hepatozoon felis DNA was detected in Rhipicephalus sanguineus sensu lato ticks in Turkey [13] and Portugal [14]. Even though feline hepatozoonosis caused by $\mathrm{H}$. felis is usually subclinical and the majority of infected cats presented no specific clinical signs [12], a fatal infection caused by Hepatozoon silvestris with the presence of Hepatozoon meronts associated with lymphoplasmacytic and histiocytic myocarditis was reported in a cat from Switzerland [15].

Considering that several vector-borne agents may occur in cats, the present work aimed to investigate the occurrence and molecular identity of tick-borne agents (Ehrlichia, Anaplasma, Babesia/Theileria, Cytauxzoon, and Hepatozoon) in cats in southeastern (states of São Paulo and Minas Gerais) and northern (state of Rondônia) Brazil.

\section{Results}

\subsection{PCR Assays for Gapdh mammalian Endogenous gene}

All cats' blood samples were positive in the PCR assay for the endogenous gene (gapdh). The mean genomic DNA concentration, 260/280, and 260/230 ratios were $35.37 \mathrm{ng} / \mu \mathrm{L}$, 1.77 , and 0.57 , respectively. 


\subsection{PCR Assays for Anaplasma spp. and Ehrlichia spp.}

Out of the 390 samples analyzed, $7.4 \%(12.3 \%$ [19/155] and 6.6\% [10/151] cats from Minas Gerais and São Paulo state, respectively) were positive in the nPCR based on the $16 \mathrm{~S}$ rRNA gene of Anaplasma spp. Out of the 26 positive samples, 5 were chosen for sequencing due to the higher band intensity observed in the agarose gel electrophoresis. All 26 samples were negative in PCR assays based on the glt $A$ gene and the 23S-5S intergenic region.

A total of $2 \%$ out of 390 cats $(4.5 \%$ [7/155] and $0.6 \%$ [1/151] of cats from the states of Minas Gerais and São Paulo, respectively) were positive in the CPCR assay for Ehrlichia spp. based on the $d s b$ gene. Unfortunately, no samples were sequenced due to low band intensity on agarose gel electrophoresis. In front of that, a qPCR assay specific for E. canis and also based on the $d s b$ gene was performed on these positive samples. As a result, three samples $(37.5 \%[3 / 8])$ were positive in the qPCR, but the samples were not quantified due to the low amount of E. canis DNA in the tested samples (Monte Carlo effect). The efficiency, $\mathrm{R}^{2}$, slope, and Y-intercept showed values of $99.7 \%, 0.988,-3.330$, and 40.629 , respectively. No samples were positive in PCR assays based on groEL, sodB, and omp-1 genes, precluding additional molecular characterization.

\subsection{PCR Assays for Piroplasmida}

\subsubsection{Babesia spp. and Theileria spp.}

Out of the 390 samples analyzed, $0.7 \%$ (0.6\% [1/155] from Minas Gerais, $0.6 \%$ [1/151] from São Paulo, and 1.2\% [1/84]) were positive in the nPCR based on the 18S rRNA gene of Babesia spp./Theileria spp. No samples were positive in the PCR assays for additional molecular characterization based on the cox-1, hsp 70, $\beta$-tubulin, cytB, and the intergenic region (ITS1).

\subsubsection{Cytauxzoon spp.}

Out of the 390 samples, $27.2 \%$ (41.9\% [65/155], 24.5\% [37/151], and 4.8\% [4/84] from Minas Gerais, São Paulo, and Rondônia states, respectively) were positive in the PCR based on the 18S rRNA gene of Cytauxzoon spp. Out of the 106 positive samples, seven were chosen for sequencing due to higher band intensity in the agarose gel electrophoresis. No samples were positive in the nPCR assay based on the intergenic region (ITS-1).

\subsubsection{Hepatozoon spp.}

No blood sample was positive for Hepatozoon spp. in the nPCR based on the 18S rRNA gene.

\subsection{Co-positivity for Anaplasmataceae and Piroplasmida Agents}

In total, 10 samples showed co-positivity between the tested agents. Out of these, eight were positive for both Cytauxzoon sp. and Anaplasma sp. (six and two from Minas Gerais and São Paulo, respectively), one for Cytauxzoon sp. and Ehrlichia sp., and one for Cytauxzoon sp. and B. vogeli, both from the state of Minas Gerais (Table 1).

Table 1. Co-positivity by tick-borne agents in cats sampled in southeastern (states of São Paulo e Minas Gerais) and northern (state of Rondônia) Brazil.

\begin{tabular}{cccccccc}
\hline & \multicolumn{3}{c}{ Co-Positivity } & \multicolumn{3}{c}{ Positivity for Only One Agent } \\
\cline { 2 - 8 } State & $\begin{array}{c}\text { Cytauxzoon } \\
+ \text { Anaplasma }\end{array}$ & $\begin{array}{c}\text { Cytauxzoon } \\
+ \text { Ehrlichia }\end{array}$ & $\begin{array}{c}\text { Cytauxzoon + Babesial } \\
\text { Theileria }\end{array}$ & $\begin{array}{c}\text { Anaplasma } \\
\text { Ehrlichia }\end{array}$ & $\begin{array}{c}\text { Babesial } \\
\text { Theileria }\end{array}$ & Cytauxzoon \\
\hline São Paulo & 2 & 0 & 0 & 8 & 1 & 1 & 35 \\
Minas Gerais & 6 & 1 & 1 & 13 & 6 & 0 & 57 \\
Rondônia & 0 & 0 & 0 & 0 & 0 & 1 & 2 \\
Total & 8 & 1 & 1 & 21 & 7 & 96 \\
\hline
\end{tabular}




\subsection{BLAST and Phylogenetic Analyses}

BLASTn analysis results are presented in Table 2.

Table 2. Percentage of identity assessed by BLASTn of Anaplasma sp., Babesia sp. and Cytauxzoon sp. sequences detected in cats from Brazil.

\begin{tabular}{|c|c|c|c|c|c|c|}
\hline Cat ID & $\begin{array}{l}\text { Target } \\
\text { Gene }\end{array}$ & $\begin{array}{c}\text { Query } \\
\text { Length (bp) }\end{array}$ & $\begin{array}{l}\text { Query-Coverage } \\
(\%)\end{array}$ & E-Value & $\begin{array}{l}\text { Identity } \\
\quad(\%)\end{array}$ & GenBank Acession Numbers \\
\hline MG03 & $r r s$ & 281 & 100 & $4 \times 10^{-143}$ & 100 & $\begin{array}{c}\text { 'Candidatus Anaplasma } \\
\text { amazonensis'—Bradypus variegatus } \\
\text { from Brazil (MT199833) }\end{array}$ \\
\hline MG21 & $r r s$ & 372 & 100 & 0 & 100 & $\begin{array}{c}\text { 'Candidatus Anaplasma } \\
\text { amazonensis' — Bradypus variegatus } \\
\text { from Brazil (MT199831) }\end{array}$ \\
\hline MG31 & $r r s$ & 543 & 100 & 0 & 97.61 & $\begin{array}{c}\text { Anaplasma } \\
\text { phagocytophilum-Hydropotes inermis } \\
\text { from Korea (KR611598) }\end{array}$ \\
\hline MG33 & $r r s$ & 398 & 99 & 0 & 99.75 & $\begin{array}{c}\text { Anaplasma spp.-Nasua nasua from } \\
\text { Brazil (MT019560) }\end{array}$ \\
\hline SP79 & $r r s$ & 522 & 99 & 0 & 100 & $\begin{array}{c}\text { Anaplasma sp.-Mazama gouazoubira } \\
\text { from Brazil (JF952891) }\end{array}$ \\
\hline ROI01 & 18S rRNA & 766 & 100 & 0 & 100 & $\begin{array}{c}\text { Babesia vogeli_cat from China } \\
\text { (MN067709) }\end{array}$ \\
\hline MG68 & 18S rRNA & 763 & 100 & 0 & 100 & $\begin{array}{c}\text { Babesia vogeli_cat from China } \\
\text { (MN067709) }\end{array}$ \\
\hline MG71 & 18S rRNA & 218 & 100 & $3 \times 10^{-108}$ & 100 & $\begin{array}{l}\text { Cytauxzoon sp.-Leopardus pardalis } \\
\text { from Brazil (MT458054) }\end{array}$ \\
\hline MG52 & 18S rRNA & 248 & 99 & $3 \times 10^{-124}$ & 100 & $\begin{array}{c}\text { Cytauxzoon sp.-Leopardus pardalis } \\
\text { from Brazil (MT458054) }\end{array}$ \\
\hline MG125 & 18S rRNA & 118 & 100 & $6 \times 10^{-53}$ & 100 & $\begin{array}{l}\text { Cytauxzoon sp.-Leopardus pardalis } \\
\text { from Brazil (MT458054) }\end{array}$ \\
\hline SP121 & 18S rRNA & 140 & 100 & $5 \times 10^{-65}$ & 100 & $\begin{array}{l}\text { Cytauxzoon sp.-Leopardus pardalis } \\
\text { from Brazil (MT458054) }\end{array}$ \\
\hline SP131 & 18S rRNA & 140 & 100 & $5 \times 10^{-65}$ & 100 & $\begin{array}{l}\text { Cytauxzoon sp.-Leopardus pardalis } \\
\text { from Brazil (MT458054) }\end{array}$ \\
\hline ROI06C & 18S rRNA & 273 & 100 & $1 \times 10^{-138}$ & 100 & $\begin{array}{l}\text { Cytauxzoon sp.-Leopardus pardalis } \\
\text { from Brazil (MT458054) }\end{array}$ \\
\hline
\end{tabular}

The phylogenetic analysis by ML and TPM $2+\mathrm{I}+\mathrm{G}$ evolutionary model (246 bp alignment) based on the rrs gene of Anaplasma spp. positioned the sequences detected in cats from Minas Gerais state into the 'Candidatus Anaplasma amazonensis' clade, recently described in sloths sampled in Brazil with 95\% branch support. On the other hand, the sequence detected in a cat from São Paulo state was allocated with sequences of Anaplasma sp. detected in gray-brocket deer (Mazama gouazoubira) from Brazil, with $94 \%$ branch support in a clade close to Anaplasma platys clade (Figure 1).

The phylogenetic analysis by ML and TIM3 + I + G evolutionary model (605 bp alignment) based on the $18 \mathrm{~S}$ rRNA gene of piroplasmids positioned the sequences detected in one cat from Minas Gerais and one cat from Rondônia into the Babesia vogeli clade previously detected in dogs and cats from Brazil and China, with $69 \%$ branch support. Unfortunately, the sequence detected in one cat from São Paulo state presented low quality and was removed from the analysis (Figure 2). 


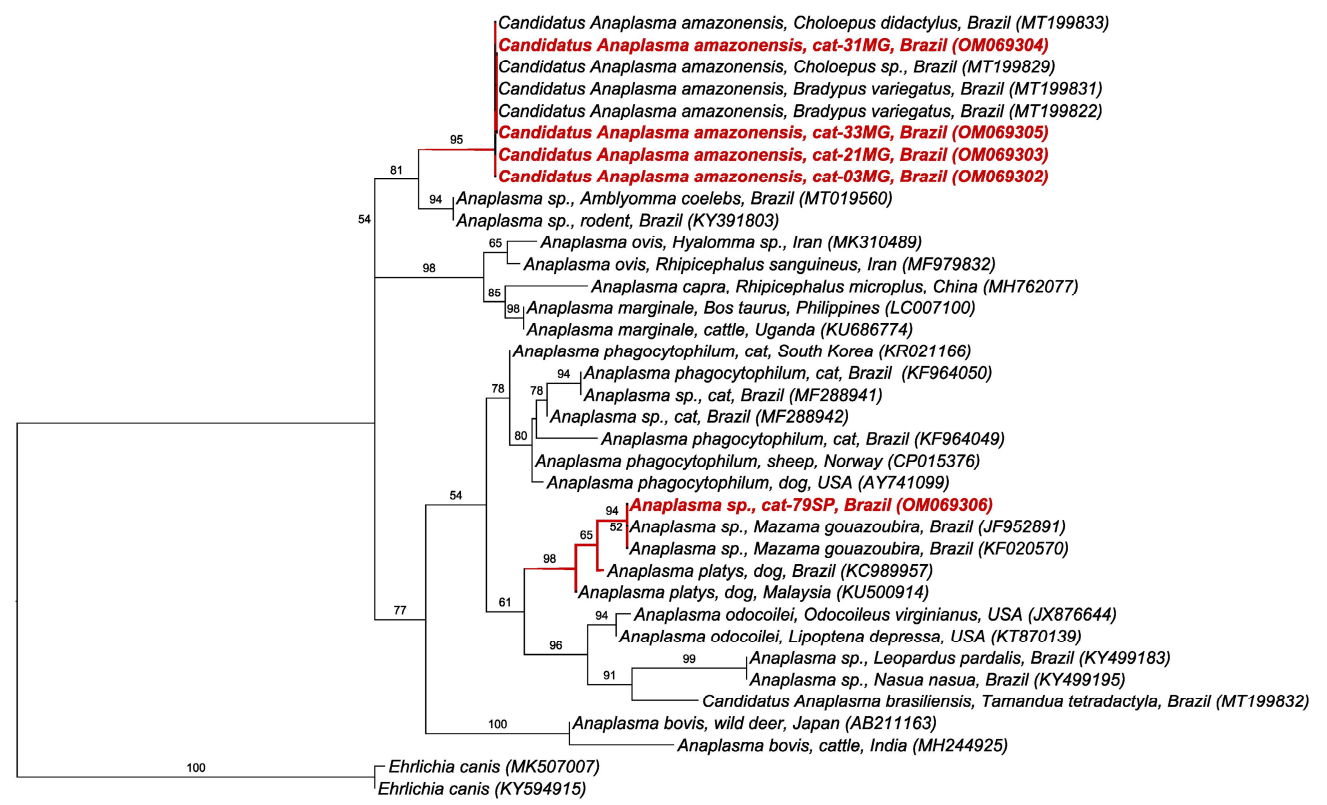

Figure 1. Phylogenetic tree based on an alignment of $246 \mathrm{bp}$ of Anaplasma sp. rrs gene, using maximum likelihood method and TPM2 + I + G as an evolutionary model. Sequences from the present study were highlighted in red. Ehrlichia canis was used as an outgroup.

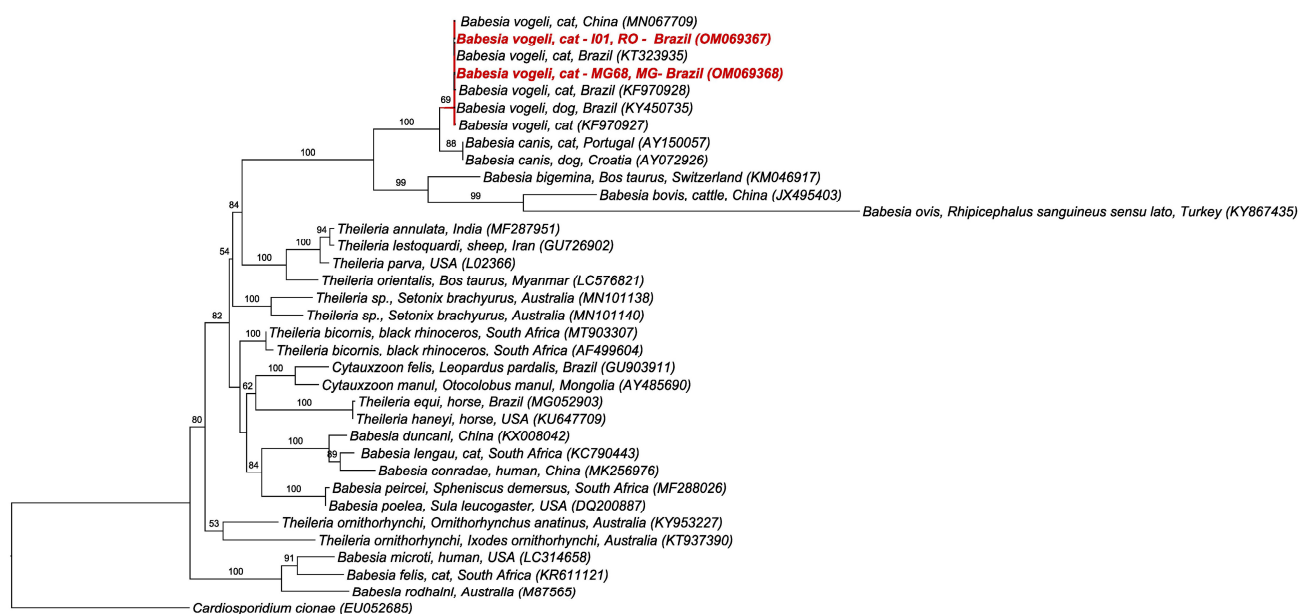

Figure 2. Phylogenetic tree based on an alignment of $605 \mathrm{bp}$ of piroplasmids $18 \mathrm{~S}$ rRNA gene, using maximum likelihood method and TIM $3+\mathrm{I}+\mathrm{G}$ as an evolutionary model. Sequences from the present study were highlighted in red. Cardiosporidium cionae was used as an outgroup.

Finally, the phylogenetic analysis by ML and TPM3 + G evolutionary model (118 bp alignment) based on the 18S rRNA gene of Cytauxzoon spp. positioned the sequences detected in cats from this study in the same clade containing Cytauxzoon sp. sequences detected in cats and ocelots from Brazil and Chile, with 66\% branch support (Figure 3). 


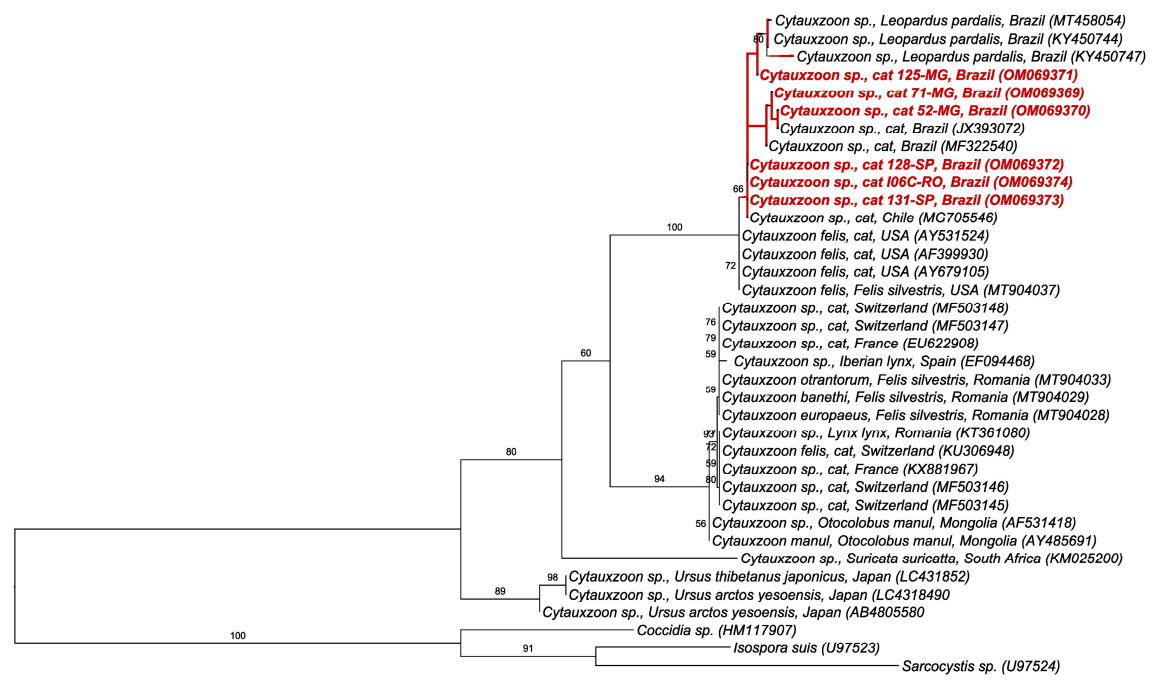

Figure 3. Phylogenetic tree based on an alignment of 118 bp of Cytauxzoon sp. 18S rRNA gene, using maximum likelihood method and TPM $3+\mathrm{G}$ as an evolutionary model. Sequences from the present study were highlighted in red. Coccidia sp., Isospora suis, and Sarcocystis sp. were used as an outgroup.

\section{Discussion}

Herein, the positivity in the nPCR assay for Anaplasma sp. was 7.4\% (12.3\% (MG) and $6.6 \%(\mathrm{SP})$ ). Previous studies conducted in Brazil reported molecular positivity ranging from $3.7 \%$ to $8 \%[7,16,17]$. The present study showed, for the first time, the occurrence of 'Candidatus Anaplasma amazonensis' in cats and the first molecular detection of Anaplasma sp. in cats in the state of Minas Gerais, adding to the list of Anaplasma species/genotypes that can infect cats in Brazil. 'Candidatus Anaplasma amazonensis' has been recently detected in sloths from northern Brazil [18]. Additionally, a genotype closely related to Anaplasma previously detected in brocket deer (Mazama gouazoubira) and dog-associated A. platys were also detected in cats in the present study. The pathogenic potential of these Anaplasma genotypes in cats is still unknown. For instance, even though A. platys was molecularly detected in a cats presenting apathy, anorexia, thrombocytopenia, and leucocytosis in the state of Pernambuco, northeastern Brazil, the PCR-positivity for $A$. platys was not associated with clinical signs and hematological abnormalities in cats sampled in the state of Rio de Janeiro [17,19]. Anaplasma rrs genotypes closely related to A. phagocytophilum have been previously detected in cats in the states of São Paulo [7], Rio Grande do Norte [20], and Santa Catarina [16]. Considering that competent tick vectors (Ixodes persulcatus complex) for A. phagocytophilum are not present in Brazil, these rrs genotypes might represent a putative novel species yet to be isolated and better characterized. On the other hand, Anaplasma phagocytophilum has been the main Anaplasmataceae agent detected in cats in the USA and Europe, where the molecular occurrence ranged from $0 \%$ to $6.9 \%$ and $0 \%$ to $23.1 \%$ (reviewed by Schafer and Kohn, 2020 [3]). Unfortunately, the lack of amplification for three additional molecular markers ( $g$ lt $A$, groEL, and ITS 23S-5S) precluded further molecular characterization. Considering that we only obtained a small fragment of the rrs gene, future phylogenetic inferences based on larger fragments are needed in order to confirm the genetic identity of these Anaplasma genotypes detected in cats.

The positivity in the PCR assay for E. canis in cats found in the present study was 2\% (MG 4.5\%; SP 0.6\%; RO 0\%), whereas previous studies from Brazil reported positivity rates ranging from $1 \%$ to $20 \%[8,16,17,21,22]$. Indeed, E. canis has been shown to be the most frequently detected Anaplasmataceae agent in cats from Brazil, and it has already been reported in the states of Minas Gerais [23], Maranhão [21], Mato Grosso [22], Mato Grosso do Sul [8], Rio Grande do Norte [20], Rio de Janeiro [17], and Santa Catarina [16]. Additionally, E. canis has already been detected in cats from the USA [24], Portugal [14], and Angola [25]. Even though the low intensity of the obtained $d s b$ amplicons in the agarose 
gel electrophoresis precluded the sequencing of the amplified products in the conventional PCR for Ehrlichia spp., a qPCR assay specific for E. canis based on the $d s b$ gene confirmed the molecular identity of the ehrlichial agent infecting some cats in the states of São Paulo and Minas Gerais. Among the eight samples positive in the cPCR for Ehrlichia spp., three also showed to be positive in the qPCR for E. canis. Even though qPCR is considered to be more sensitive than $\mathrm{CPCR}$, the Monte Carlo effect [26] might have hampered the detection and reproducibility in samples with a very low amount of $E$. canis DNA. Considering that both $E$. canis and its vector, the brown dog tick ( $R$. sanguineus sensu lato) are endemic in most of the Brazilian states, except for the state of Rio Grande do Sul [5,27], the occurrence of $E$. canis in cats in different Brazilian regions might reflect the prevalence of both pathogen and tick vector in dogs and the environmental infestation with $R$. sanguineus sensu lato. The pathogenic potential of $E$. canis in cats, solely or associated with other hemoparasites, deserves further studies. Anemia was statistically associated with seropositivity to $E$. canis in cats from Rio de Janeiro [17]. A cat positive in the PCR for E. canis in the state of Minas Gerais showed to be thrombocytopenic [23]. Ehrlichia canis-PCR-positive cats in the state of Mato Grosso, central-western Brazil, showed a tendency to be lymphopenic and thrombocytopenic [22]. This is the first report on the occurrence of E. canis in cats from the state of São Paulo.

A low positivity ( $0.7 \%$ ) for Babesia/Theileria (MG 0.6\%; SP 0.6\%; RO 1.2\%) was found among cats sampled in the present study. This is the first report of $B$. vogeli in cats from the states of Rondônia e Minas Gerais. Previous studies in Brazil found positivity rates ranging from $4 \%$ to $16 \%$ in cats in the states of São Paulo [7], Mato Grosso do Sul [8], and Rio Grande do Sul [27]. Babesia vogeli has also been detected in cats from Thailand [28], Portugal [29], Saint Kitts [30], and Qatar [31]. According to Penzhorn (2020) [6], the widespread distribution of dog-associated $B$. vogeli in cats is not a surprise due to the cosmopolitan distribution of its vector, the tick $R$. sanguineus sensu lato. It seems that immunocompetent cats deal with the infection without discernible clinical and hematological abnormalities. Nevertheless, experimental studies should be performed in order to check the progression of $B$. vogeli infection in cats.

On the other hand, high positivity in the PCR for Cytauxzoon was found among cats sampled in the states of Minas Gerais (41.9\%) and São Paulo (24.5\%). This is the first report of Cytauxzoon in domestic cats in the three mentioned states. Cats sampled in the states of SP and MG, where higher numbers of PCR-positive cats were observed, were apparently healthy since they were submitted to spay/neutering procedures. Apparently, these cats might have been infected by a non-pathogenic strain of Cytauxzoon. This high number of positive cats might be related to exposure to an infected tick vector endemic to both areas. Unfortunately, information about outdoor access and exposure to ticks were not available, precluding the assessment of associated risk factors for positivity. Some cats sampled in SP and MG were parasitized by Ctenocephalides felis felis fleas at the time of blood sampling (data not shown) [32]. It is most likely that positive cats might have presented long-lasting erythroparasitemia and may act as reservoirs for non-pathogenic strains of Cytauxzoon in Brazil, which should be confirmed by experimental infection of cats with Brazilian strains of Cytauxzoon. Neotropical wild felids likely play a role as reservoirs for Cytauxzoon in Brazil [33,34], probably presenting short and self-limiting schizogony as previously observed in bobcats (Lynx rufus), which act as reservoirs for C. felis in the USA [9]. As far as authors are concerned, fatal cytauxzoonosis has not been reported in domestic cats in Brazil, despite reports of fatal cytauxzoonosis in lions (Panthera leo) [35] and jaguars (Panthera onca) [36] in the country. Actually, despite the detection of piroplasms in cats' erythrocytes [20,37], schizonts have not been detected in domestic cats from Brazil so far. These findings suggest that several isolates may occur in the country, whose pathogenicity may differ from each other. The recent description of three new Cytauxzoon species, namely C. otrantorum, C. banethi, and C. europaeus, in wild felids from Europe expands the diversity of Cytauxzoon species other than C. felis and C. manul [38]. Herein, the $18 \mathrm{~S}$ rRNA fragments of Cytauxzoon sp. detected in the sampled cats grouped 
with Cytauxzoon sequences previously detected in wild felids from Brazil and domestic cats from Chile. Even though the fragment used was conserved and small, the topology suggests a slight separation between Cytauxzoon isolates from Brazil and C. felis from the USA. Nonetheless, these findings should be confirmed with phylogenetic assessments based on near-full $18 \mathrm{~S}$ rRNA and mitochondrial genes. The apparent low pathogenicity of Brazilian strains of Cytauxzoon differs from that observed for North American C. felis isolates, despite the phylogenetic proximity between them. Interestingly, European species of Cytauxzoon also seem to show low pathogenicity when compared to C. felis. In front of that, we suggest using the denomination Cytauxzoon sp. for Brazilian isolates instead of C. felis until further data obtained from mitochondrial and whole-genome sequencing are achieved, allowing a better phylogenetic/phylogenomics positioning.

None of the sampled cats showed to be positive in a nested PCR assay for Hepatozoon sp. based on the 18S rRNA. This finding was not a surprise since reports of Hepatozoon infection in cats in Brazil are scarce. The few works found in the literature reported a low molecular positivity $(0.5 \%-1.6 \%)$ for Hepatozoon in cats in the states of Maranhão [39], Mato Grosso do Sul [8], and Mato Grosso [40]. In Brazil, phylogenetic studies based on the 18S rRNA showed that H. canis, H. felis, and Hepatozoon, closely related to H. americanum, can infect cats [8,39-41]. Hepatozoon felis has already been detected in cats from Spain [42], Italy [43,44], Angola [25], South Africa [45], Cabo Verde [46], and Austria [47]. On the other hand, H. canis has already been detected in cats from Spain [42] and Italy [43]. Following the same pattern for the previously mentioned tick-borne agents, the real significance of Hepatozoon infection in cats from Brazil is unknown. Previously, a cat naturally infected by H. canis in the state of São Paulo presented gamonts in neutrophils, renal failure, anorexia, lethargy, leucopenia, and severe anemia [41,48]. Clinical cases of feline hepatozoonosis without coinfection with other infectious agents were also described in cats infected by Hepatozoon silvestris and H. felis from Switzerland [15] and Austria [47], respectively.

Co-positivity by Cytauxzoon and one more TBA (Anaplasma, Ehrlichia, and Babesia/Theileria) was confirmed in 10 cats' blood samples. Previously in Brazil, coinfection by E. canis, Anaplasma closely related to A. phagocytophilum, and Cytauxzoon was found in cats presenting non-specific clinical signs in the state of Rio Grande do Norte, northeastern Brazil [20]. Coinfection by several vector-borne agents in cats seems to be more usual than previously thought [8]. The consequences of coinfection by several TBA in cats deserve more attention by veterinary practitioners. Future studies aiming at verifying the impact of TBA in cats in single or co-infections are much needed.

Finally, keeping in mind that A. platys [49] and E. canis [48] have already been detected in humans and considering the close contact between cats and owners, special attention is needed regarding feline vector-borne agents. Regarding that, the role of cats as a sentinel for tick-borne diseases should not be neglected.

This body of work presents two main limitations. One of them relies on the fact that we were not able to sequence all the obtained amplicons due to the faint bands obtained in the agarose gel electrophoresis. Without sequencing, we could not confirm the molecular identity of the positive sample obtained in the nested PCR for Babesia/Theileria from a cat sampled in Jaboticabal, SP. Similarly, even though the used nested PCR assay for Anaplasma is considered specific for this genus, we cannot rule out the amplification of a closely related agent DNA using this protocol. Likewise, despite the few amplicons sequenced, the protocol used herein for detecting a fragment of Cytauxzoon 18S rRNA is considered quite specific for this Piroplasmida genus. Nonetheless, without sequencing all the amplicons, we cannot rule out the occurrence of false positives due to non-specific amplification. Because of that, we used the term "positivity in PCR assays" instead of occurrence throughout the manuscript. The second limitation is the lack of additional information regarding the clinical and laboratorial findings of the cats sampled in the present study, which precluded inferences on the possible association between the studied TBA and the manifestation of disease. In addition, the lack of information regarding epidemiological variables (e.g., outdoor access, history of ectoparasite infestation, contact 
with other animal species, estimated age, etc.) hampered the assessment of possible risk factors associated with the positivity for Ehrlichia, Anaplasma, and piroplasmids.

\section{Materials and Methods}

\subsection{Cats' Blood Sampling}

Between the months of August and September 2018, 390 blood samples were collected from domiciled cats in Minas Gerais (155 samples-Uberlândia $19^{\circ} 00^{\prime} 39^{\prime \prime} \mathrm{S} 48^{\circ} 05^{\prime} 45^{\prime \prime} \mathrm{W}$ and Araguari $18^{\circ} 24^{\prime} 43^{\prime \prime} \mathrm{S} 49^{\circ} 03^{\prime} 09^{\prime \prime} \mathrm{W}$ ), São Paulo (151 samples-Jaboticabal $21^{\circ} 15^{\prime} 33^{\prime \prime} \mathrm{S}$ $48^{\circ} 18^{\prime} 54^{\prime \prime} \mathrm{W}$ ) and Rondônia (84 samples—Rolim de Moura $11^{\circ} 43^{\prime} 21.8^{\prime \prime} \mathrm{S} 61^{\circ} 46^{\prime} 29.5^{\prime \prime} \mathrm{W}$ ) states (Figure 4). These samples were collected with the consent of the animals' tutors during neutering campaigns promoted by the Animal Protector Association Neutering Center, located at the School of Agricultural and Veterinarian Sciences (FCAV/ UNESP, Jaboticabal, São Paulo State, Southeastern Brazil), Animal Populational Control Project a partnership by the Federal University of Uberlândia (UFU) and the city's Zoonosis Control Center (Uberlândia, Minas Gerais State) [32] and by researchers of Universidade Federal de Rondônia. All procedures were authorized and approved by the Animal Use Ethics Committee of the Universidade Estadual Paulista (IACUC FCAV/UNESP 012017/17). Blood samples were collected in tubes containing EDTA, transported in liquid nitrogen to the laboratory, and stored in a freezer $\left(-80^{\circ} \mathrm{C}\right)$ until sample processing.

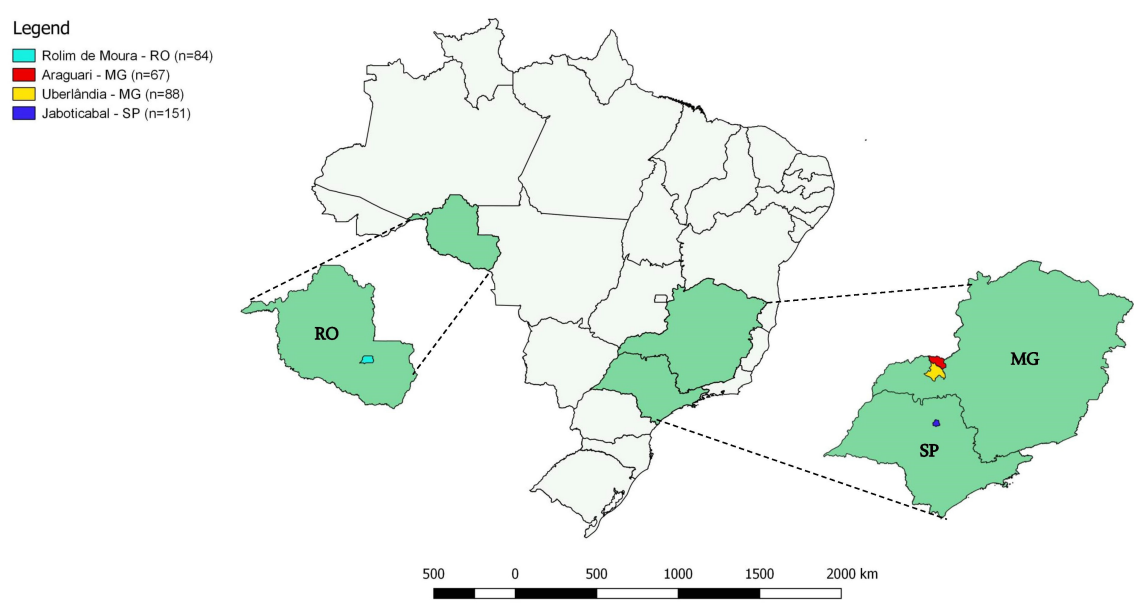

Figure 4. Map showing the location of the cities of Rolim de Moura (Rondônia State), Uberlândia and Araguari (Minas Gerais State), and Jaboticabal (São Paulo State), where cats were sampled in the present study.

\subsection{DNA Extraction from Cats' Blood Samples and PCR Assays for Mammalian endogenous gene}

DNA was extracted from $250 \mu \mathrm{L}$ from each blood sample according to the protocol described by Kuramae-Izioka (1997) [50]. The quantification of total genomic DNA, as well as the measurement of the $260 / 280$ and $230 / 280$ ratios of the extracted desoxirrobonucleic acids, were performed in a Nanodrop device (Thermo Scientific ${ }^{\circledR}$ ) by reading the absorbance of each sample. The presence of amplifiable DNA in cats' blood samples was verified by a conventional PCR assay targeting the mammal endogenous glyceraldehyde-3phosphate dehydrogenase (gapdh) gene [51]. Only the samples that were positive in this PCR assay were used in the following PCR assays aiming at detecting Anaplasmataceae and Piroplasmida DNA.

\subsection{PCR Assays for Anaplasma spp. and Ehrlichia spp.}

For Anaplasma spp. DNA detection, a nested (n)PCR assay based on the rrs gene was performed [52]. Subsequently, the positive samples for Anaplasma spp. were tested by an nPCR based on the gltA gene [53] and a conventional (c)PCR targeting the 23S-5S intergenic region of Anaplasma spp. [54], respectively (Table 3). For Ehrlichia spp. DNA 
detection, a cPCR based on the $d s b$ gene was performed [55]. The positive samples for Ehrlichia spp. were tested by cPCR assays based on the groEL [56], sodB [57], and omp-1 [58] genes (Table 3). The cPCR assays were performed using $5 \mu \mathrm{L}$ of the DNA samples in a mixture containing 1.25 U Platinum Taq DNA Polymerase (Invitrogen, Carlsbad, California, USA), PCR buffer (PCR buffer $10 \times, 100 \mathrm{nM}$ Tris- $\mathrm{HCl}, \mathrm{pH} 9.0,500 \mathrm{mM} \mathrm{KCl}), 0.2 \mathrm{mM}$ deoxynucleotides (dATP, dTTP, dCTP, and dGTP) (Invitrogen, Carlsbad, California, United States), $1.5 \mathrm{mM}$ of magnesium chloride (Invitrogen, Carlsbad, CA, USA), $0.5 \mu \mathrm{M}$ of each primer (Invitrogen), and sterile ultrapure water (Invitrogen) q.s. $25 \mu \mathrm{L}$. In nPCR assays, $1 \mu \mathrm{L}$ of the amplified product from the first PCR reaction was used as the target DNA in the second reaction. DNA samples from A. phagocytophilum, kindly provided by Professor John Stephen Dumler (Uniformed Services University of the Health Sciences, Bethesda, MD, USA), and E. canis, obtained from DH82 cells infected with the Jaboticabal strain of E. canis [59], were used as positive controls. Sterile ultrapure water (Nuclease-Free Water, Promega Corporation) was used as a negative control.

Table 3. Description of primers, amplicons size and thermal sequences used in conventional and nested PCR assays for Ehrlichia, Anaplasma, Babesia/Theileria, Cytauxzoon and Hepatozoon.

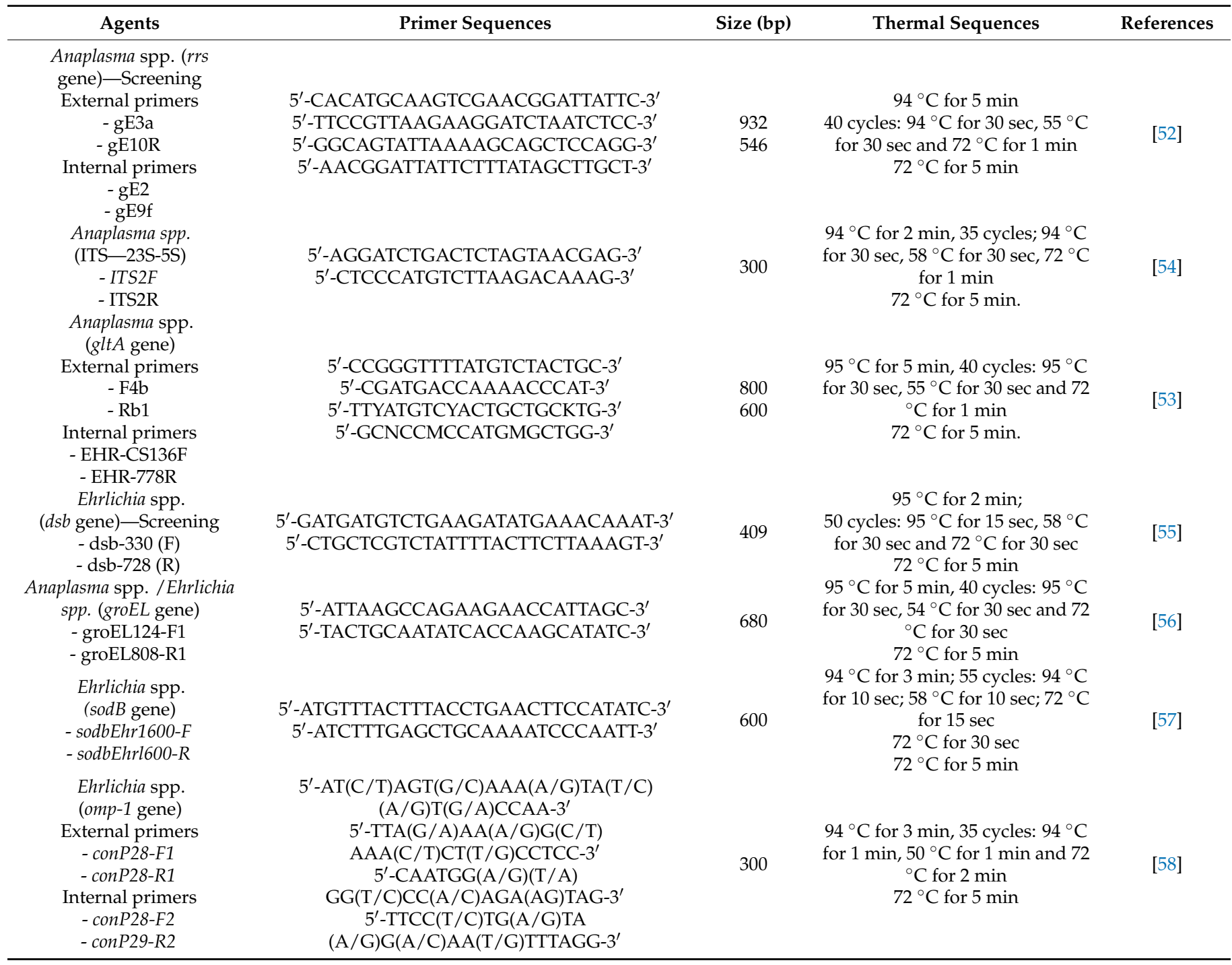


Table 3. Cont.

\begin{tabular}{|c|c|c|c|c|}
\hline Agents & Primer Sequences & Size (bp) & Thermal Sequences & References \\
\hline $\begin{array}{c}\text { Piroplasmida } \\
\text { (18S rRNA)- Screening } \\
\text { External primers } \\
\text { - BTF1 } \\
\text { - BTR1 } \\
\text { Internal primers } \\
\text { - BTF2 } \\
\text { - BTR2 }\end{array}$ & $\begin{array}{c}\text { 5'-GGCTCATTACAACAGTTATAG-3' } \\
\text { 5'-CCCAAAGACTTTGATTTCTCTC-3' } \\
\text { 5'-CCGTGCTAATTGTAGGGCTAATAC-3' } \\
\text { 5'-GGACTACGACGGTATCTGATCG-3' }\end{array}$ & 800 & $\begin{array}{c}94{ }^{\circ} \mathrm{C} \text { for } 3 \mathrm{~min}, 58^{\circ} \mathrm{C} \text { for } 1 \mathrm{~min} \text {, } \\
72{ }^{\circ} \mathrm{C} \text { for } 2 \mathrm{~min} 45 \mathrm{cycles}: 94{ }^{\circ} \mathrm{C} \\
\text { for } 30 \mathrm{sec}, 58{ }^{\circ} \mathrm{C} \text { for } 20 \mathrm{sec} \text { and } 72 \\
{ }^{\circ} \mathrm{C} \text { por } 30 \mathrm{sec} \\
72{ }^{\circ} \mathrm{C} \text { por } 7 \mathrm{~min} \\
\text { Annealing temperature of the } \\
\text { 2nd reaction }=62{ }^{\circ} \mathrm{C}\end{array}$ & {$[60]$} \\
\hline $\begin{array}{l}\text { Babesia sp./Theileria sp. } \\
\text { (cox-1 gene) } \\
\text { External primers } \\
\text { - Bab_for1 } \\
\text { - Bab_Rev1 } \\
\text { Internal primers } \\
\text { - Bab_for2 } \\
\text { - Bab_rev2 }\end{array}$ & $\begin{array}{c}\text { 5'-ATWGGATTYTATATGAGTAT-3' }^{\prime} \\
\text { 5'-ATAATCWGGWATYCTCCTTGG-3' }^{\prime} \\
\text { 5'-TCTCTWCATGGWTTAATTATGATAT-3 }^{\prime} \\
\text { 5'-TAGCTCCAATTGAHARWACAAAGTG-3' }^{\prime}\end{array}$ & 924 & $\begin{array}{c}95^{\circ} \mathrm{C} \text { for } 1 \mathrm{~min}, \\
35 \text { cycles; } 95^{\circ} \mathrm{C} \text { for } 15 \mathrm{sec}, 45^{\circ} \mathrm{C} \\
\text { for } 30 \mathrm{sec} \text { and } 72{ }^{\circ} \mathrm{C} \text { for } 1 \mathrm{~min} \\
72{ }^{\circ} \mathrm{C} \text { por } 10 \mathrm{~min} \\
\text { Annealing temperature of the } \\
\text { 2nd reaction }=49^{\circ} \mathrm{C}\end{array}$ & [61] \\
\hline $\begin{array}{l}\text { Babesia sp./Theileria sp. } \\
\text { (hsp70 gene) } \\
\text { - Hsp70F1 } \\
\text { - Hsp70R1 }\end{array}$ & $\begin{array}{c}\text { 5'-CATGAAGCACTGGCCHTTCAA-3'3 } \\
\text { 5'-GCNCKGCTGATGGTGGTGTTGTA-3' }\end{array}$ & 740 & $\begin{array}{l}95^{\circ} \mathrm{C} \text { for } 5 \mathrm{~min} \\
35 \text { cycles: } 95^{\circ} \mathrm{C} \text { for } 15 \mathrm{sec}, 60{ }^{\circ} \mathrm{C} \\
\text { for } 30 \mathrm{sec} \text { and } 72{ }^{\circ} \mathrm{C} \text { for } 30 \mathrm{sec} \\
72^{\circ} \mathrm{C} \text { for } 5 \mathrm{~min}\end{array}$ & [62] \\
\hline $\begin{array}{l}\text { Babesia sp./Theileria sp. } \\
\text { ( } \beta \text {-tubulin gene) } \\
\text { - Tubo3 } \\
\text { - Tubo63F }\end{array}$ & $\begin{array}{l}\text { 5'-CAAATWGGYGCMAARTTYTGGGA-3' } \\
\text { 5'-TCGTCCATACCTTCWCCSGTRTACCAGTG-3' }\end{array}$ & 600 & $\begin{array}{l}\quad 94{ }^{\circ} \mathrm{C} \text { for } 5 \text { minues } \\
30 \text { cycles: } 94{ }^{\circ} \mathrm{C} \text { for } 40 \mathrm{sec}, 55^{\circ} \mathrm{C} \\
\text { for } 1 \text { min and } 72{ }^{\circ} \mathrm{C} \text { for } 90 \mathrm{sec} ; 72 \\
{ }^{\circ} \mathrm{C} \text { for } 5 \mathrm{~min}\end{array}$ & [63] \\
\hline $\begin{array}{c}\text { Babesia sp./Theileria sp. } \\
\text { (cytB gene) } \\
\text { External primers } \\
\text { - Bc_cytB_F1 } \\
\text { - Bc_cytB_R1 } \\
\text { Internal primers } \\
\text { - Bc_cytB_F2 } \\
\text { - Bc_cytB_R2 }\end{array}$ & $\begin{array}{c}\text { 5'-TGGTCWTGGTATTCWGGAATG-3' } \\
\text { 5'-AAGMYARTCTYCCTAAACATCC-3' }^{\prime} \\
\text { 5'-RATKAGYTAYTGGGGAGC-3' } \\
\text { 5'-GCTGGWATCATWGGTATAC-3' }\end{array}$ & 580 & $\begin{array}{l}95^{\circ} \mathrm{C} \text { for } 5 \mathrm{~min} \\
40 \text { cycles: } 95^{\circ} \mathrm{C} \text { for } 45 \mathrm{sec}, 55^{\circ} \mathrm{C} \\
\text { for } 45 \mathrm{sec} \text { and } 72{ }^{\circ} \mathrm{C} \text { for } 45 \mathrm{sec} \text {. } \\
72{ }^{\circ} \mathrm{C} \text { por } 10 \mathrm{~min} \text {; Temp. } \\
\text { Annealing temperature of the } \\
\text { 2nd reaction }=52^{\circ} \mathrm{C}\end{array}$ & [64] \\
\hline $\begin{array}{l}\text { Babesia sp./Theileria } \\
\text { sp./Cytauxzoon sp. } \\
\text { (intergenic region ITS-1) } \\
\text { External primers } \\
\text { - ITS15C } \\
\text { - ITS13B } \\
\text { Internal primers } \\
\text { - ITS15D } \\
\text { - ITS13C }\end{array}$ & $\begin{array}{c}\text { 5'-CGATCGAGTGATCCGGTGAATTA-3' } \\
\text { 5'-GCTGCGTCCTTCATCGTTGTG-3' } \\
\text { 5'-AAGGAAGGAGAAGTCGTAACAAGG-3' } \\
\text { 5'-TTGTGTGAGCCAAGACATCCA-3' }\end{array}$ & 500 & $\begin{array}{l}94{ }^{\circ} \mathrm{C} \text { for } 1 \mathrm{~min} \\
35 \text { cycles: } 94{ }^{\circ} \mathrm{C} \text { for } 30 \mathrm{sec}, 52{ }^{\circ} \mathrm{C} \\
\text { for } 30 \mathrm{sec} \text { and } 72{ }^{\circ} \mathrm{C} \text { for } 1 \mathrm{~min} \text {. } \\
72{ }^{\circ} \mathrm{C} \text { for } 5 \mathrm{~min} \text {; } \\
\text { Annealing temperature of the } \\
\text { 2nd reaction }=49^{\circ} \mathrm{C}\end{array}$ & [65] \\
\hline $\begin{array}{l}\text { Cytauxzoon sp. } \\
\text { (18S rRNA)-Screening } \\
\text { - CytF } \\
\text { - CytR }\end{array}$ & $\begin{array}{l}\text { 5'-GCGAATCGCATTGCTTTATGCT-3' } \\
\text { 5'-CCAAATGATACTCCGGAAAGAG-3' }\end{array}$ & 300 & $\begin{array}{l}95^{\circ} \mathrm{C} \text { for } 5 \mathrm{~min} \\
40 \text { cycles: } 95^{\circ} \mathrm{C} \text { for } 45 \mathrm{sec}, 59^{\circ} \mathrm{C} \\
\text { for } 45 \mathrm{sec} \text { and } 72{ }^{\circ} \mathrm{C} \text { for } 1 \mathrm{~min} \text {. } \\
72{ }^{\circ} \mathrm{C} \text { for } 5 \mathrm{~min} \\
1 \text { st reaction: }\end{array}$ & {$[66]$} \\
\hline $\begin{array}{c}\text { Hepatozoon sp. } \\
\text { (18S rRNA)—Screening } \\
\text { External Primers } \\
\text { - HAM1 } \\
\text { - HPF2 } \\
\text { Internal primers } \\
\text { - } 4558 \\
\text { - } 2733\end{array}$ & $\begin{array}{c}\text { 5'-GCCAGTAGTCATATGCTTGTC-3' } \\
\text { 5'-GACTTCTCCTTCGTCTAAG-3' }^{\prime} \\
\text { 5'-GCTAATACATGAGCAAAATCTCAA-3' } \\
\text { 5'-CGGAATTAACCAGACAAAT-3' }\end{array}$ & 1120 & $\begin{array}{l}95^{\circ} \mathrm{C} \text { for } 3 \mathrm{~min} \\
40 \text { cycles: } 95^{\circ} \mathrm{C} \text { for } 1 \mathrm{~min}, 56{ }^{\circ} \mathrm{C} \\
\text { for } 1 \mathrm{~min} \text { and } 72{ }^{\circ} \mathrm{C} \text { for } 1 \mathrm{~min} \text {. } \\
72{ }^{\circ} \mathrm{C} \text { for } 7 \mathrm{~min} \\
2 \mathrm{nd} \text { reaction: } \\
94^{\circ} \mathrm{C} \text { for } 3 \mathrm{~min} \\
40 \text { cycles: } 94{ }^{\circ} \mathrm{C} \text { for } 1 \mathrm{~min}, 55^{\circ} \mathrm{C} \\
\text { for } 2 \text { min and } 72{ }^{\circ} \mathrm{C} \text { for } 2 \mathrm{~min} . \\
72{ }^{\circ} \mathrm{C} \text { for } 10 \mathrm{~min}\end{array}$ & [67-69] \\
\hline
\end{tabular}

Additionally, a specific qPCR assay for E. canis based on the $d s b$ gene [55] was performed on the positive samples for Ehrlichia sp. The assay was performed with a final volume of $10 \mu \mathrm{L}$ containing $1 \mu \mathrm{L}$ of DNA sample, $0.2 \mu \mathrm{M}$ of each primer (F: $5^{\prime}-$ TTGCAAAATGATGTCTGAAGATATGAAACA- $3^{\prime}$ and R: $5^{\prime}$-GCTGCTCCACCAATAAATG TATCYCCTA- $3^{\prime}$ ) and hydrolysis probe (5' FAM AGCTAGTGCTGCTTGGGCAACTTTGA GTGAA-(BHQ-1-3' $)$ ), $5 \mu$ L GoTaq Probe qPCR Master Mix (Promega Corporation, Madison WI, USA), and sterilized ultrapure water (Nuclease-Free Water; Promega Corporation) q.s. $9 \mu \mathrm{L}$. The thermal conditions used were $95^{\circ} \mathrm{C}$ for 5 minutes, followed by 40 cycles 
of $95^{\circ} \mathrm{C}$ for 15 seconds and $60{ }^{\circ} \mathrm{C}$ for 1 minute. PCR amplifications were performed in low-profile multiplate unskirted PCR plates (Bio-Rad, Hercules, CA USA) using a CFX96 Thermal Cycler (Bio-Rad). Quantification of the number of copies of target DNA/ $\mu \mathrm{L}$ was performed using IDT psmart plasmids (Integrated DNA Technologies, Coralville, IA, USA) containing the target sequences. Serial dilutions were performed to construct standard curves with different plasmid DNA concentrations $\left(2.0 \times 10^{7}\right.$ to $2.0 \times 10^{0}$ copies $\left./ \mu \mathrm{L}\right)$. The number of plasmid copies/ $\mu \mathrm{L}$ of the amount $(\mathrm{g} / \mu \mathrm{L})$ of DNA/plasmid (bp) was determined by multiplying by $6.022 \times 10^{23}$. Each qPCR assay was performed in duplicate for each DNA sample. All duplicates showing cycle quantification $(\mathrm{Cq})$ values differing by $>0.5$ were re-tested. Amplification efficiency (E) was calculated from the slope of the standard curve in each run $\left(\mathrm{E}=10^{-1 / \text { slope }}\right)$. The reactions followed the standards established by the Minimum Information for Publication of Quantitative Real-time PCR Experiments [26].

\subsection{PCR Assays for Piroplasmida}

\subsubsection{Babesia spp. and Theileria spp.}

An nPCR assay that amplifies a fragment of the $18 \mathrm{~S}$ rRNA gene of piroplasmids (Jefferies et al., 2007) was performed to detect Babesia/Theileria spp. in the DNA samples. Positive samples in this assay were tested by cPCR assays based on the cox-1 [61], hsp70 [62], $\beta$-tubulin [63], and cytB [64] genes and the intergenic region (ITS-1) [65] (Table 3). The assays were performed using $5 \mu \mathrm{L}$ of the DNA samples in a mixture containing $0.75 \mathrm{U}$ Platinum Taq DNA Polymerase (Invitrogen, Carlsbad, CA, USA), PCR buffer (PCR buffer $10 \times-100 \mathrm{nM}$ Tris-HCl, pH 9.0, $500 \mathrm{mM} \mathrm{KCl}$ ), $0.2 \mathrm{mM}$ deoxynucleotides (dATP, dTTP, dCTP, and dGTP) (Invitrogen, Carlsbad, CA, USA), $1.5 \mathrm{mM}$ of Magnesium chloride (Invitrogen, Carlsbad, CA, USA), $0.5 \mu \mathrm{M}$ of each primer (Invitrogen), and sterile ultrapure water (Invitrogen) q.s. $25 \mu \mathrm{L}$. In nPCR assays, $1 \mu \mathrm{L}$ of the amplified product from the first PCR reaction was used as the target DNA in the second reaction. A DNA sample obtained from a dog experimentally infected with Babesia vogeli (Jaboticabal strain) [70] was used as a positive control. Sterile ultrapure water (Nuclease-Free Water, Promega Corporation, Madison, WI, USA) was used as a negative control.

\subsubsection{Cytauxzoon spp.}

PCR assays based on the $18 \mathrm{~S}$ rRNA gene were performed to detect Cytauxzoon spp. DNA in cats' blood samples [66]. Subsequently, the positive samples were subjected to an nPCR assay that amplified a fragment of the intergenic region (ITS-1) [65] (Table 3). The assays were performed using $5 \mu \mathrm{L}$ of the DNA samples in a mixture containing $1.25 \mathrm{U}$ Platinum Taq DNA Polymerase (Invitrogen, Carlsbad, California, USA), PCR buffer (PCR buffer $10 \times-100 \mathrm{nM}$ Tris- $\mathrm{HCl}, \mathrm{pH} 9.0,500 \mathrm{mM} \mathrm{KCl}$ ), $0.2 \mathrm{mM}$ deoxynucleotides (dATP, dTTP, dCTP, and dGTP) (Invitrogen, Carlsbad, CA, USA), $1.5 \mathrm{mM}$ of magnesium chloride (Invitrogen, Carlsbad, CA, USA), $0.4 \mu \mathrm{M}$ of each primer (Invitrogen), and sterile ultrapure water (Invitrogen) q.s. $25 \mu \mathrm{L}$. In nPCR assays, $1 \mu \mathrm{L}$ of the amplified product from the first PCR reaction was used as the target DNA in the second reaction. DNA samples of Cytauxzoon sp. from an ocelot sampled in the Pantanal of Mato Grosso do Sul [34] and ultrapure sterilized water were used as positive and negative controls, respectively.

\subsection{PCR assay for Hepatozoon spp.}

For detection of Hepatozoon spp. DNA, an nPCR assay based on the 18S rRNA gene was performed [67-69] (Table 3). The nPCR assay was performed using $5 \mu \mathrm{L}$ of the DNA samples in a mixture containing 0.75 U Platinum Taq DNA Polymerase (Invitrogen, Carlsbad, CA, USA), PCR buffer (PCR buffer $10 \times-100 \mathrm{nM}$ Tris-HCl, pH 9.0, $500 \mathrm{mM}$ $\mathrm{KCl}$ ), $0.2 \mathrm{mM}$ deoxynucleotides (dATP, dTTP, dCTP, and dGTP) (Invitrogen, Carlsbad, CA, USA), $1.5 \mathrm{mM}$ of magnesium chloride (Invitrogen, Carlsbad, CA, USA), $1.25 \mu \mathrm{M}$ of each primer (Invitrogen), and sterile ultrapure water (Invitrogen) q.s. $25 \mu \mathrm{L}$. A total of $1 \mu \mathrm{L}$ of the amplified product from the first PCR reaction was used as the target DNA in the second reaction. Hepatozoon sp. DNA detected in a naturally infected maned-wolf (Chrysocyon 
brachyurus) was used as a positive control [71]. Sterile ultrapure water (Nuclease-Free Water, Promega Corporation) was used as a negative control.

\subsection{Agarose Gel Electrophoresis}

The amplified products were subjected to horizontal electrophoresis on a $1.5 \%$ agarose gel stained with ethidium bromide $(0.5 \mu \mathrm{L} / \mathrm{mL})$ in TEB running buffer $\mathrm{pH} 8.0(44.58 \mathrm{M}$ Trisbase; 0, $44 \mathrm{M}$ boric acid; $12.49 \mathrm{mM}$ EDTA). Electrophoresis was performed at $100 \mathrm{~V} / 50 \mathrm{~mA}$ for 40 minutes. To determine the size of amplified products, a 100 base pair molecular weight marker (Life Technologies ${ }^{\circledR}$ ) was used. The results were visualized and analyzed using an ultraviolet light transilluminator coupled to a computer image analysis program (ChemiDoc Imaging System, Bio-Rad ${ }^{\circledR}$ ).

\subsection{Purification of PCR Amplified Products and Sequencing}

After the PCR assays for Anaplasma spp., Ehrlichia spp., piroplasmids, and Hepatozoon spp., the amplified products were purified using Exosap IT PCR Product Cleanup Reagent (Applied Biosystems, Foster City, CA, USA), according to the manufacturer's recommendations. The sequencing of the amplified products was performed through an automated system based on the method of chain termination by dideoxynucleotide [72]. The sequencing was performed in the ABI PRISM 3700 DNA Analyzer (AppliedBiosystems) sequencer at the Center for Biological Resources and Genomic Biology (CREBIO-FCAV-UNESP).

\subsection{Phylogenetic Analyses}

The sequences obtained were submitted to a quality-screening test using Phred-Phrap software (version 23) [73,74] to evaluate the quality of the electropherograms and to obtain the consensus sequences from the alignment of the sense and antisense sequences. The BLASTn program [75] was used to compare the obtained nucleotide sequences with previously deposited sequences in the GenBank database [76]. The sequences saved in "FASTA" format were aligned with other homologous sequences of each agent retrieved from the database (GenBank), using the Mafft software [77] and edited via Bioedit v. 7.0.5.3 [78]. The "best of it" evolutionary model was selected from the sequence alignment matrices using the jModelTest 2 software [79]. W-IQ-Tree software was used for the choice of the evolutionary model following BIC criterion and for phylogenetic analysis by the maximum likelihood method (available online: http://iqtree.cibiv.univie.ac.at/) [80], while clade support indices were evaluated through bootstrap analyses [81] of 1000 repetitions. The editing of phylogenetic trees as well as rooting (via outer group) were performed using the Treegraph 2.0.56-381 beta software [82].

\section{Conclusions}

The present study showed the occurrence of TBA (E. canis, Anaplasma sp., B. vogeli, and Cytauxzoon) in cats from southeastern and northern Brazil, expanding the list and geographical distribution of such hemoparasites in cats. 'Candidatus Anaplasma amazonensis', recently detected in sloths from northern Brazil, was described for the first time in cats. The dog-associated B. vogeli, E. canis, and A. platys were molecularly detected in cats from the present study, suggesting environmental infestation with $R$. sanguineus sensu lato, the vector for all three hemoparasites. This is the first report of piroplasmids infecting cats in northern Brazil. Coinfection by Cytauxzoon and other TBA (Ehrlichia, Anaplasma, and Babesia/Theileria) was reported in the present study, which raises the need for veterinary practitioners' awareness of cats parasitized by multiple TBA.

Author Contributions: Conceptualization, M.R.A.; Data curation, A.C.C.; Formal analysis, A.C.C. and M.R.A.; Funding acquisition, M.R.A.; Investigation, M.R.A., M.A.P.F., R.Z.M.; Methodology, A.C.C., M.E.C.F., I.d.A., P.V.C.A., L.C.d.M.L., C.A.d.P.L., I.K.L.d.N.D.; Project administration, M.R.A.; Resources, M.R.A.; Software, A.C.C.; Supervision, M.R.A.; Validation, A.C.C., M.R.A., M.A.P.F., R.Z.M.; Writing—original draft, A.C.C. and M.R.A.; Writing—review and editing, A.C.C. and M.R.A. All authors have read and agreed to the published version of the manuscript. 
Funding: This work was supported by FAPESP (Foundation for Research Support of the State of São Paulo: \#2018/02753-0; \#2020/12037-0; 2020/12773-8; 2020/07826-5; 2019/26109-5; 2019/19027-2; 2019/10101-5) and CNPq (National Council for Scientific and Technological Development; Productivity Grant to MRA [CNPq Process \#302420/2017-7]. M.E.C.F. received scholarship from CAPES (Coordenação de Aperfeiçoamento de Pessoal de Nível Superior).

Institutional Review Board Statement: All procedures were authorized and approved by the Animal Use Ethics Committee of the Universidade Estadual Paulista (IACUC FCAV/UNESP 012017/17).

Informed Consent Statement: Informed consent for participating to the study was obtained from all the involved owners.

Data Availability Statement: The obtained nucleotide sequences were deposited in Genbank under the following accession numbers OM069302-OM069306; OM069367-OM069374.

Acknowledgments: The authors are grateful to Foundation for Research Support of the State of São Paulo (FAPESP), National Council for Scientific and Technological Development (CNPq), and Programa de Pós-Graduação em Ciências Veterinárias (PPGCVet-FCAV/UNESP).

Conflicts of Interest: The authors declare no conflict of interest.

\section{References}

1. Dumler, J.S.; Barbet, A.F.; Bekker, C.P.J.; Dasch, G.A.; Palmer, G.H.; Stuart, C.R.; Rikihisa, Y.; Rrurangirwa, F.R. Reorganization of genera in the families Rickettsiaceae and Anaplasmataceae in the Order Rickettsiales: Unification of some species of Ehrlichia with Anaplasma, Cowdria with Ehrlichia and Ehrlichia with Neorickettsia, descriptions of six news species combinations and designation of Ehrlichia equi and 'HGE agent'as subjective synonyms of Ehrlichia phagocytophila. Int. J. Syst. Evol. Microbiol. 2001, 51, 2145-2165.

2. Pennisi, M.G.; Hofmann-Lehmann, R.; Radford, A.D.; Tasker, S.; Belák, S.; Addie, D.D.; Boucraut-Baralon, C.; Egnerink, H.; Frymus, T.; Gruffydd-Jones, T.; et al. Anaplasma, Ehrlichia and Rickettsia species infections in cats: European guidelines from the ABCD on prevention and management. J. Feline Med. Surg. 2017, 19, 542-548. [CrossRef]

3. Schäfer, I.; Kohn, B. Anaplasma phagocytophilum infection in cats: A literature review to raise clinical awareness. J. Feline Med. Surg. 2020, 22, 428-441. [CrossRef]

4. Moraes-Filho, J.; Krawczak, F.S.; Costa, F.B.; Soares, J.F.; Labruna, M.B. Comparative evaluation of the vector competence of four South American populations of the Rhipicephalus sanguineus group for the bacterium Ehrlichia canis, the agent of canine monocytic ehrlichiosis. PLoS ONE 2015, 10, e0139386. [CrossRef]

5. Snellgrove, A.N.; Krapiunaya, I.; Ford, S.L.; Stanley, H.M.; Wickson, A.G.; Hartzer, K.L.; Levin, M.L. Vector competence of Rhipicephalus sanguineus sensu stricto for Anaplasma platys. Ticks Tick Borne Dis. 2020, 11, 101517. [CrossRef]

6. Penzhorn, B.L.; Oosthuizen, M.C. Babesia Species of Domestic Cats: Molecular Characterization Has Opened Pandora's Box. Front. Vet. Sci. 2020, 7, 134. [CrossRef] [PubMed]

7. André, M.R.; Denardi, N.C.B.; de Sousa, K.C.M.; Gonçalves, L.R.; Henrique, P.C.; Ontivero, C.R.G.R.; Ontivero, C.R.G.R.; Gonzalez, I.H.L.; Nery, C.V.C.; Chagas, C.R.F.; et al. Arthropod-borne pathogens circulating in free-roaming domestic cats in a zoo environment in Brazil. Ticks Tick Borne Dis. 2014, 5, 545-551. [CrossRef] [PubMed]

8. $\quad$ André, M.R.; Herrera, H.M.; Fernandes, S.J.; de Sousa, K.C.M.; Gonçalves, L.R.; Domingos, I.H.; Domingos, I.H.; Macedo, G.C.; Machado, R.Z. Tick-borne agents in domesticated and stray cats from the city of Campo Grande, state of Mato Grosso do Sul, midwestern Brazil. Ticks Tick Borne Dis. 2015, 6, 779-786. [CrossRef]

9. Wang, J.L.; Li, T.T.; Liu, G.H.; Zhu, X.Q.; Yao, C. Two tales of Cytauxzoon felis infections in domestic cats. Clin. Microbiol. Rev. 2017, 30, 861-885. [CrossRef]

10. Lloret, A.; Addie, D.D.; Boucraut-Baralon, C.; Egberink, H.; Frymus, T.; Gruffydd-Jones, T.; Hartmann, K.; Horzinek, M.C.; Hosie, M.J.; Lutz, H.; et al. Cytauxzoonosis in cats: ABCD guidelines on prevention and management. J. Feline Med. Surg. 2015, 17, 637-641. [CrossRef] [PubMed]

11. Smith, T.G. The genus hepatozoon (apicomplexa: Adeleina). J. Parasitol. 1996, 82, 565-585. [CrossRef] [PubMed]

12. Lloret, A.; Addie, D.D.; Boucraut-Baralon, C.; Egberink, H.; Frymus, T.; Jones-Gruffydd, T.; Hartmann, K.; Horzinek, M.C.; Hosie, M.J.; Lutz, H.; et al. Hepatozoonosis in cats: ABCD guidelines on prevention and management. J. Feline Med. Surg. 2015, 17, 642-644. [CrossRef] [PubMed]

13. Aktas, M. A survey of ixodid tick species and molecular identification of tick-borne pathogens. Vet. Parasitol. 2014, 200, 276-283. [CrossRef]

14. Maia, C.; Ferreira, A.; Nunes, M.; Vieira, M.L.; Campino, L.; Cardoso, L. Molecular detection of bacterial and parasitic pathogens in hard ticks from Portugal. Ticks Tick Borne Dis. 2014, 5, 409-414. [CrossRef] [PubMed]

15. Kegler, K.; Nufer, U.; Alic, A.; Posthaus, H.; Olias, P.; Basso, W. Fatal infection with emerging apicomplexan parasite Hepatozoon silvestris in a domestic cat. Parasit. Vectors 2018, 11, 428. [CrossRef]

16. Pedrassani, D.; Biolchi, J.; Gonçalves, L.R.; Mendes, N.S.; Zanatto, D.C.D.S.; Calchi, A.C.; Machado, R.Z.; André, M.R. Molecular detection of vector-borne agents in cats in Southern Brazil. Rev. Bras. Parasitol. Vet. 2019, 28, 632-643. [CrossRef] [PubMed] 
17. Guimarães, A.; Raimundo, J.M.; Rodrigues, R.B.; Peixoto, M.P.; Santos, H.A.; André, M.R.; Machado, R.Z.; Baldani, C.D. Ehrlichia spp. infection in domestic cats from Rio de Janeiro State, southeast Brazil. Rev. Bras. Parasitol. Vet. 2019, 28, 180-185. [CrossRef] [PubMed]

18. Calchi, A.C.; Vultão, J.G.; Alves, M.H.; Yogui, D.R.; Desbiez, A.L.J.; De Santi, M.; Santana, M.S.; da Silva, T.M.V.; Werther, K.; Teixeira, M.M.G.; et al. Ehrlichia spp. and Anaplasma spp. in Xenarthra mammals from Brazil, with evidence of novel 'Candidatus Anaplasma spp.'. Sci. Rep. 2020, 10, 126115.

19. Lima, M.L.F.; Soares, P.T.; Ramos, C.A.N.; Araújo, F.R.; Ramos, R.A.N.; Souza, I.I.F.; Faustino, M.A.G.; Alves, L.C.A. Molecular detection of Anaplasma platys in a naturally-infected cat in Brazil. Braz. J. Microbiol. 2010, 41, 381-385. [CrossRef]

20. André, M.R.; Filgueira, K.D.; Calchi, A.C.; Sousa, K.C.M.D.; Gonçalves, L.R.; Medeiros, V.B.; Ximenes, P.A.; Lelis, I.C.N.G.; Meireles, M.V.N.; Machado, R.Z. Co-infection with arthropod-borne pathogens in domestic cats. Rev. Bras. Parasitol. Vet. 2017, 26, 525-531. [CrossRef]

21. Braga, M.D.S.C.D.O.; André, M.R.; Freschi, C.R.; Teixeira, M.C.A.; Machado, R.Z. Molecular and serological detection of Ehrlichia spp. in cats on São Luís Island, Maranhão, Brazil. Rev. Bras. Parasitol. Vet. 2012, 21, 37-41. [CrossRef] [PubMed]

22. Braga, Í.A.; Santos, L.G.F.D.; Melo, A.L.T.; Jaune, F.W.; Ziliani, T.F.; Girardi, Â.F.; Aguiar, D.M.D. Hematological values associated to the serological and molecular diagnostic in cats suspected of Ehrlichia canis infection. Rev. Bras. Parasitol. Vet. 2013, 22, 470-474. [CrossRef]

23. De Oliveira, L.S.; Mourão, L.C.; Oliveira, K.A.; Agostini, M.M.; De Oliveira, A.C.; De Almeida, J.L.; Fietto, J.L.R.; Conceição, L.G.; Filho, J.D.R.; Galvão, M.A.M.; et al. Molecular detection of Ehrlichia canis in cats in Brazil. Clin. Microbiol. Infect. 2009, 15, 53-54. [CrossRef] [PubMed]

24. Breitschwerdt, E.B.; Abrams-Ogg, A.C.; Lappin, M.R.; Bienzle, D.; Hancock, S.I.; Cowan, S.M.; Hawkins, E.C. Molecular evidence supporting Ehrlichia canis-like infection in cats. J. Vet. Int. Med. 2002, 16, 642-649. [CrossRef]

25. Oliveira, A.C.; Luz, M.F.; Granada, S.; Vilhena, H.; Nachum-Biala, Y.; Lopes, A.P.; Cardoso, L.; Baneth, G. Molecular detection of Anaplasma bovis, Ehrlichia canis and Hepatozoon felis in cats from Luanda, Angola. Parasit. Vectors 2018, 11, 167. [CrossRef] [PubMed]

26. Bustin, S.A.; Benes, V.; Garson, J.A.; Hellemans, J.; Huggett, J.; Kubista, M.; Mueller, R.; Nolan, T.; Pfaffl, M.W.; Shipley, G.L.; et al. The MIQE guidelines: Minimum Information for Publication of Quantitative Real-Time PCR Experiments. Clin. Chem. 2009, 55, 611-622. [CrossRef]

27. Malheiros, J.; Costa, M.M.; Do Amaral, R.B.; De Sousa, K.C.M.; André, M.R.; Machado, R.Z.; Vieira, M.I.B. Identification of vector-borne pathogens in dogs and cats from Southern Brazil. Ticks Tick Borne Dis. 2016, 7, 893-900. [CrossRef]

28. Simking, P.; Wongnakphet, S.; Stich, R.W.; Jittapalapong, S. Detection of Babesia vogeli in stray cats of metropolitan Bangkok, Thailand. Vet. Parasitol. 2010, 173, 70-75. [CrossRef]

29. Vilhena, H.; Martinez-Díaz, V.L.; Cardoso, L.; Vieira, L.; Altet, L.; Francino, O.; Pastor, J.; Silvestre-Ferreira, A.C. Feline vectorborne pathogens in the north and centre of Portugal. Par Vect. 2013, 6, 99. [CrossRef]

30. Kelly, P.J.; Köster, L.; Li, J.; Zhang, J.; Huang, K.; Branford, G.M.; March, S.; Vandenplas, M.; Wang, C. Survey of vector-borne agents in feral cats and first report of Babesia gibsoni in cats on St Kitts, West Indies. BMC Vet. Res. 2017, 13, 331. [CrossRef]

31. Alho, A.M.; Lima, C.; Latrofa, M.S.; Colella, V.; Ravagnan, S.; Capelli, G.; Otranto, D. Molecular detection of vector-borne pathogens in dogs and cats from Qatar. Par Vect. 2017, 10, 298. [CrossRef] [PubMed]

32. Furquim, M.E.C.; do Amaral, R.; Dias, C.M.; Gonçalves, L.R.; Perles, L.; de Paula Lima, C.A.; Barros-Battesti, D.M.; Machado, R.Z.; André, M.R. Genetic diversity and Multilocus Sequence Typing Analysis of Bartonella henselae in domestic cats from Southeastern Brazil. Acta Trop. 2021, 222, 106037. [CrossRef] [PubMed]

33. André, M.R.; Adania, C.H.; Machado, R.Z.; Allegretti, S.M.; Felippe, P.A.; Silva, K.F.; Nakagui, A.C.H.; Dagnone, A.S. Molecular detection of Cytauxzoon spp. in asymptomatic Brazilian wild captive felids. J. Wildl. Dis. 2009, 45, 234-237. [CrossRef]

34. de Sousa, K.C.M.; Fernandes, M.P.; Herrera, H.M.; Freschi, C.R.; Machado, R.Z.; André, M.R. Diversity of piroplasmids among wild and domestic mammals and ectoparasites in Pantanal wetland, Brazil. Ticks Tick Borne Dis. 2018, 9, 245-253. [CrossRef]

35. Peixoto, P.V.; Soares, C.O.; Scofield, A.; Santiago, C.D.; Franca, T.N.; Barros, S.S. Fatal cytauxzoonosis in captive-reared lions in Brazil. Vet. Parasitol. 2007, 145, 383-387. [CrossRef]

36. Guizelini, C.C.; Nascimento, C.A.; Echeverria, J.T.; Soares, R.L.; Pimenta, M.M.; de Deco-Souza, T.; Gomes, D.C. Fatal infection caused by Cytauxzoon felis in a captive-reared jaguar (Panthera onca). Int. J. Parasitol. Parasites Wildl. 2021, 16, 187-190. [CrossRef]

37. Raimundo, J.M.; Guimarães, A.; André, M.R.; Baldani, C.D. Cytauxzoon felis DNA detection in healthy cats from Rio de Janeiro, Brazil. J. Parasitol. 2021, 107, 676-678. [CrossRef]

38. Panait, L.C.; Mihalca, A.D.; Modrý, D.; Juránková, J.; Ionică, A.M.; Deak, G.; Gherman, C.M.; Heddergott, M.; Hodzic, A.; Veronesi, F; ; et al. Three new species of Cytauxzoon in European wild felids. Vet. Parasitol. 2021, 290, 109344. [CrossRef] [PubMed]

39. de Bortoli, C.P.; André, M.R.; Braga, M.S.C.; Machado, R.Z. Molecular characterization of Hepatozoon sp. in cats from São Luís Island, Maranhão, northeastern Brazil. Parasitol. Res. 2011, 109, 1189-1192. [CrossRef]

40. Braga, I.A.; Ramos, D.G.S.; Marcili, A.; Melo, A.L.T.; Taques, I.I.G.G.; Amude, A.M.; Chitarra, C.S.; Nakazato, L.; Dutra, V.; Pacheco, R.C.; et al. Molecular detection of tick-borne protozoan parasites in a population of domestic cats in midwestern Brazil. Ticks Tick Borne Dis. 2016, 7, 1004-1009. [CrossRef] [PubMed]

41. Rubini, A.S.; Paduan, K.S.; Perez, R.R.; Ribolla, P.E.M.; O’Dwyer, L.H. Molecular characterization of feline Hepatozoon species from Brazil. Vet. Parasitol 2006, 137, 168-171. [CrossRef] 
42. Díaz-Regañón, D.; Villaescusa, A.; Ayllón, T.; Rodríguez-Franco, F.; Baneth, G.; Calleja-Bueno, L.; Garcia-Sancho, M.; Agulla, B.; Sainz, Á. Molecular detection of Hepatozoon spp. and Cytauxzoon sp. in domestic and stray cats from Madrid, Spain. Parasit. Vectors 2017, 10, 112. [CrossRef]

43. Giannelli, A.; Latrofa, M.S.; Nachum-Biala, Y.; Hodžić, A.; Greco, G.; Attanasi, A.; Annoscia, G.; Otranto, D.; Baneth, G. Three different Hepatozoon species in domestic cats from southern Italy. Ticks Tick Borne Dis. 2017, 8, 721-724. [CrossRef]

44. Grillini, M.; Simonato, G.; Tessarin, C.; Dotto, G.; Traversa, D.; Cassini, R.; Marchiori, E.; Frangipane di Regalbono, A. Cytauxzoon sp. and Hepatozoon spp. in domestic cats: A preliminary study in North-Eastern Italy. Pathogens 2021, 10, 1214. [CrossRef]

45. Harris, D.J.; Santos, J.; Rampedi, K.M.; Halajian, A.; Xavier, R. Genetic diversity of Hepatozoon (Apicomplexa) from domestic cats in South Africa, with a global reassessment of Hepatozoon felis diversity. J. S. Afr. Vet. Assoc. 2019, 90, 1747. [CrossRef] [PubMed]

46. Pereira, C.; Maia, J.P.; Marcos, R.; Luzzago, C.; Puente-Payo, P.; Dall'Ara, P.; Faustino, A.; Lauzi, S. Molecular detection of Hepatozoon felis in cats from Maio Island, Republic of Cape Verde and global distribution of feline hepatozoonosis. Parasit. Vectors 2019, 12, 294. [CrossRef] [PubMed]

47. Basso, W.; Görner, D.; Globokar, M.; Keidel, A.; Pantchev, N. First autochthonous case of clinical Hepatozoon felis infection in a domestic cat in Central Europe. Parasitol Int. 2019, 72, 101945. [CrossRef]

48. Perez, R.R.; Rubini, A.S.; O'Dwyer, L.H. The first report of Hepatozoon spp. (Apicomplexa, Hepatozoidae) in domestic cats from São Paulo state, Brazil. Parasitol. Res. 2004, 94, 83-85. [CrossRef] [PubMed]

49. Maggi, R.G.; Mascarelli, E.P.; Havenga, L.N.; Naidoo, V.; Breitschwerdt, E.B. Co-infection with Anaplasma platys, Bartonella henselae and Candidatus Mycoplasma haematoparoum in a veterinarian. Parasites Vectors 2013, 6, 103. [CrossRef]

50. Kuramae-Izioka, E.E. A rapid, easy and high yield protocol for total genomic DNA isolation of Colletotrichum gloeosporioides and Fusarium oxysporum. Rev. Unimar 1997, 19, 683-689.

51. Birkenheuer, A.J.; Levy, M.G.; Breitschwerdt, E.B. Development and evaluation of a seminested PCR for detection and differentiation of Babesia gibsoni (Asian Genotype) and B. canis DNA in Canine Blood Samples. J. Clin. Microbiol. 2003, 41, $4172-4177$. [CrossRef] [PubMed]

52. Massung, R.F.; Slater, K.; Owens, J.H.; Nicholson, W.L.; Mather, T.N.; Miller, M.A.; Holder, M.T.; Vos, R.; Midford, P.E.; Liebowitz, T.; et al. Nested PCR assay for detection of granulocytic Ehrlichiae. J. Clin. Microbiol. 1998, 36, 1090-1095. [CrossRef]

53. Gofton, A.W.; Doggett, S.; Ratchford, A.; Ryan, U.; Irwin, P. Phylogenetic characterization of two Novel Anaplasmataceae from Australian Ixodes holocyclus ticks: "Candidatus Neoehrlichia australis" and "Candidatus Neoehrlichia arcana". Int. J. Syst. Evol. Microbiol. 2016, 66, 4256-4261. [CrossRef] [PubMed]

54. Rejmanek, D.; Bradburd, G.; Foley, J. Molecular characterization reveals distinct genospecies of Anaplasma phagocytophilum from diverse North American hosts. J. Med. Microbiol. 2012, 61, 204-212. [CrossRef]

55. Doyle, C.K.; Labruna, M.B.; Breitschwerdt, E.B.; Tang, Y.; Corstvet, R.E.; Hegarty, B.C.; Block, K.C.; Li, P.; Walker, D.C.; Mcbride, J.W. Detection of medically important Ehrlichia by quantitative multicolor Taq-Man Real Time PCR of the dsb gene. J. Mol. Diagn. 2005, 7, 504-510. [CrossRef]

56. Müller, A.; Monti, G.; Otth, C.; Sepúlveda, P.; Bittencourt, P.; Nachum-Bala, Y.; Gutiérresz, R.; Harrus, S. “Candidatus Neoehrlichia chilensis" sp. nov.: Molecular detection and characterization of a novel Anaplasmataceae in wild rodents from Valdivia, Southern Chile. Transbound. Emerg. Dis. 2018, 65, 357-362. [CrossRef] [PubMed]

57. O'Nion, V.L.; Montilla, H.J.; Qurollo, B.A.; Maggui, R.G.; Hegarty, B.C.; Tornquist, S.J.; Breitschwerdt, E.B. Potentially novel Ehrlichia species in horses, Nicaragua. Emerg. Infect. Dis. 2015, 21, 335-339. [CrossRef]

58. Inayoshi, M.; Naitou, H.; Kawamori, F.; Masuzawa, T.; Ohashi, N. Characterization of Ehrlichia species from Ixodes ovatus ticks at the foot of Mt.Fuji, Japan. Microbiol. Immunol. 2004, 48, 737-745. [CrossRef] [PubMed]

59. Aguiar, D.M.; Saito, T.B.; Hagiwara, M.K.; Machado, R.Z.; Labruna, M.B. Serological diagnosis of canine monocytic ehrlichiosis with Brazilian antigen of Ehrlichia canis. Cienc. Rural 2007, 37, 796-802. [CrossRef]

60. Jefferies, R.; Ryan, U.M.; Irwin, P.J. PCR-RFLP for the detection and differentiation of the canine piroplasm species and its use with filter paper-based technologies. Vet. Parasitol. 2007, 144, 20-27. [CrossRef]

61. Corduneanu, A.; Hrazdilová, K.; Sándor, A.D.; Matei, I.A.; Ionică, A.M.; Barti, J.L.; Ciocanau, M.A.; Mantoiu, D.S.; Coroiu, I.; Hornok, S.; et al. Babesia vesperuginis, a neglected piroplasmid: New host and geographical records, and phylogenetic relations. Parasit. Vectors 2017, 10, 598. [CrossRef]

62. Soares, J.F.; Girotto, A.; Brandão, P.E.; Da Silva, A.S.; França, R.T.; Lopes, S.T.; Labruna, M.B. Detection and molecular characterization of a canine piroplasm from Brazil. Vet. Parasitol. 2011, 180, 203-208. [CrossRef]

63. Zamoto, A.; Tsuji, M.; Wei, Q.; Cho, S.H.; Shin, E.H.; Kim, T.S.; Leonova, G.N.; Hagiwara, K.; Asakawa, M.; Kariwa, H.; et al. Epizootiologic survey for Babesia microti among small wild mammals in northeastern Eurasia and a geographic deversity in the $\beta$-tubulin gene sequences. J. Vet. Med. Sci. 2004, 66, 785-792. [CrossRef]

64. Hrazdilová, K.; Myśliwy, I.; Hildebrand, J.; Buńkowska-Gawlik, K.; Janaczyk, B.; Perec-Matysiak, A.; Modrý, D. Paralogs vs. genotypes? Variability of Babesia canis assessed by 18 S rDNA and two mitochondrial markers. Vet. Parasit. 2019, 266, 103-110. [CrossRef] [PubMed]

65. Shock, B.C.; Birkenheuer, A.J.; Patton, L.L.; Olfenbuttel, C.; Beringer, J.; Grove, D.M.; Peek, M.; Butfiloski, J.W.; Hughes, D.W.; Lockhart, J.M.; et al. Variation in the ITS-1 and ITS-2 rRNA genomic regions of Cytauxzoon felis from bobcats and pumas in the eastern United States and comparison with sequences from domestic cats. Vet. Parasitol. 2012, 190, 29-35. [CrossRef] 
66. Birkenheuer, A.J.; Marr, H.; Alleman, A.R.; Levy, M.G.; Breitschwerdt, E.B. Development and evaluation of a PCR assay for the detection of Cytauxzoon felis DNA in feline blood samples. Vet. Parasitol. 2006, 137, 144-149. [CrossRef] [PubMed]

67. Criado-Fornelio, A.; Ruas, J.L.; Casado, N.; Farias, N.A.R.; Soares, M.P.; Müller, G.; Brumt, J.G.W.; Berne, M.E.A.; Bulingsaraña, A.; Barba-Carretero, J.C. New molecular data on mammalian Hepatozoon species (Apicomplexa: Adeleorina) from Brazil and Spain. J. Parasitol. 2006, 92, 93-99. [CrossRef]

68. Mathew, J.S.; Van Den Bussche, R.A.; Ewing, S.A.; Malayer, J.R.; Latha, B.R.; Panciera, R.J. Phylogenetic relationships of Hepatozoon (Apicomplexa: Adeleorina) based on molecular, morphologic, and life-cycle characters. J. Parasitol. 2000, 86, 366-372. [CrossRef]

69. da Silva, M.R.L.; Fornazari, F.; Martins, T.F.; Hippólito, A.G.; Rolim, L.S.; Bisca, J.M.; O’Dwyer, L.H. A survey of hemoparasites and ectoparasites in Nasua nasua Linnaeus, 1766 with a redescription of Hepatozoon procyonis Richards, 1961 based on morphological and molecular data. Parasitol. Res. 2018, 117, 2159-2169. [CrossRef] [PubMed]

70. Furuta, P.I.; Oliveira, T.M.F.D.S.; Teixeira, M.C.A.; Rocha, A.G.; Machado, R.Z.; Tinucci-Costa, M. Comparison between a soluble antigen-based ELISA and IFAT in detecting antibodies against Babesia canis in dogs. Rev. Bras. Parasitol. Vet. 2009, 18, 41-45. [CrossRef]

71. Perles, L.; Barranco, G.H.F.; Soriano, I.M.; Cruz, N.D.R.N.; Bueno, P.J.; Santana, Á.E.; Machado, R.Z.; Werther, K.; André, M.R. Hepatozoon sp. gamonts as an accidental finding in synovial liquid from an injured maned wolf (Chrysocyon brachyurus) in southeastern Brazil. Rev. Bras. Parasitol. Vet. 2019, 28, 779-785. [CrossRef]

72. Sanger, F.; Nicklen, S.; Coulson, A.R. DNA sequencing with chain-terminating inhibitors. Proc. Natl. Acad. Sci. USA 1977, 74, 5463-5467. [CrossRef] [PubMed]

73. Ewing, B.; Hillier, L.; Wendl, M.C.; Green, P. Base-calling of automated sequencer traces using Phred. I. Acuracy Assessement Genome Res. 1998, 8, 175-1985. [CrossRef]

74. Ewing, B.; Green, P. Basecalling of automated sequencer traces using Phred. II. Error probabilities. Genome Res. 1998, 8, 186-194. [CrossRef] [PubMed]

75. Altschul, S.F.; Gish, W.; Miller, W.; Myers, E.W.; Lipman, D.J. Basic local alignment search tool. J. Mol. Biol. 1990, 215 , 403-410. [CrossRef]

76. Benson, D.A.; Cavanaugh, M.; Clark, K.; Karsch-Mizrachi, I.; Ostell, J.; Pruitt, K.D.; Sayers, E.W. GenBank. Nucleic Acids Res. 2002, 30, 17-20. [CrossRef] [PubMed]

77. Katoh, K.; Standley, D.M. MAFFT Multiple Sequence Alignment Software Version 7: Improvements in performance and usability. Mol. Biol. Evol. 2013, 30, 772-780. [CrossRef]

78. Hall, T.A. BioEdit: A user-friendly biological sequence alignment editor and analysis program for Windows 95/98/NT. Nucleic Acids Symp. Ser. 1999, 41, 95-98.

79. Darriba, D.; Taboada, G.L.; Doallo, R.; Posada, D. jModelTest 2: More models, new heuristics and parallel computing. Nat. Methods 2012, 9, 772. [CrossRef]

80. Trifinopoulos, J.; Nguyen, L.T.; Von Haeseler, A.; Minh, B.Q. W-IQ-TREE: A fast online phylogenetic tool for Maximum Likelihood Analysis. Nucleic Acids Res. 2016, 8, 232. [CrossRef]

81. Felsenstein, J. Confidence limits on phylogenies: An approach using the bootstrap. Evolution 1985, 39, 783-791. [CrossRef] [PubMed]

82. Stover, B.C.; Muller, K.F. TreeGraph 2: Combining and visualizing evidence from different phylogenetic analyses. BMC Bioinform. 2010, 11, 7. [CrossRef] [PubMed] 